\title{
«OUTIDANÒS OÛTIS». CLAVES PARA UNA BREVE GENEALOGÍA DE LA NADA
}

\section{"OUTIDANÒS OUUTIS». CLUES TO A BRIEF GENEALOGY OF NOTHINGNESS}

\author{
Mariana Chendo ${ }^{1}$ \\ Universidad del Salvador, Buenos Aires-Argentina
}

Recibido: 28-8-2015

Aceptado: 5-3-2016

Resumen: Apropiándonos de la distinción de Mourelatos entre un uso existencial y un uso atributivo de la nada en Grecia arcaica, haremos un recorrido del término outidanós en la obra homérica con la intención de mostrar que en sus orígenes arcaicos la nada (médén/oudén) no está identificada con lo que no es (tò mè ón), sino que está inscripta en un implícito proceso de clasificación y jerarquización de valores materiales. Para ello, trabajaremos el término outidanós desde la relación existencia/atribución (en Odisea), vinculándolo a la lógica de la repartición (en Ilíada).

Palabras clave: Outidanós; Nada; Nombre; Gloria; Nadie

\begin{abstract}
Appropriating Mourelatos' distinction between an existencial and a characterizing use of nothingness in ancient Greece, we will study the word outidanós in the works of Homer, trying to show that in its archaic origin, nothingess (mêdén/oudén) is not identified with what is not (tò mè ón), but registered in an implicit process of classification and hierarchy of material values. For this purpose, we will study the term outidanós from the relationship existence/ attribution (in Odyssey), linking it to a distributing logic (in Iliad).
\end{abstract}

Key words: Outidanós; Nothingness; Name; Glory; Nobody

«iRey devorador del pueblo, porque reinas entre nadies!»

(Homero, Ilíada)

1. (marianachendo@hotmail.com; mariana.chendo@usal.edu.ar) Licenciada en Filosofía (Universidad del Salvador, Buenos Aires-Argentina). Prosecretaria Académica Facultad de Ciencias de la Educación y de la Comunicación Social (Universidad del Salvador, Buenos Aires-Argentina). 
«Los nadies: los hijos de nadie, los dueños de nada.

Que no son, aunque sean.

$\cdots$

Los nadies,

que cuestan menos

que la bala que los mata.»

Eduardo Galeano, Los nadies

\section{Introducción}

Nietzsche enseña, en La genealogía de la moral, que el mundo de los conceptos morales tiene su hogar nativo «en el derecho de las obligaciones» ${ }^{2}$; pero -también para Nietzsche- la metafísica, con su cargamento ascético, termina siendo el logro más acabado de tal proceso de moralización. De este modo, la tematización de la existencia se vuelve la problematización del derecho a existir, en una genealogía que rompe el vidrio de conceptos cristalizados haciendo aflorar los fluidos que acabaron estancos a fuerza de momificación conceptual. «El pensamiento en torno al que aquí se batalla es la valoración de nuestra vida» ${ }^{3}$, en un proceso metafísico que tiene su origen oculto en «la más antigua y originaria relación personal que existe, en la relación entre compradores y vendedores, acreedores y deudores: fue aquí donde por vez primera se enfrentó la persona a la persona, fue aquí donde por vez primera las personas se midieron entre sí» ${ }^{4}$. Fijar precios, tasar, medir para compensar y compensar para valorar, «esto preocupó de tal manera al más antiguo pensamiento del hombre, que constituye, en cierto sentido, el pensar ${ }^{5}$. Nietzsche sostiene que la propia palabra alemana para «hombre» (Mensch, manas) aún expresa algo de aquel sentimiento que permite definir al hombre como el «animal tasador en sí»"

2. Nietzsche, F.: La genealogía de la moral. Alianza: Madrid, 2001, p.85.

3. Ibidem, p.151.

4. Ibidem, p.91.

5. Ídem.

6. Ídem.

Thémata. Revista de Filosofía №54 (2016) pp.: 93-110. 
pregunta ¿Quién? Es la única que nos conduce a la esencia. Porque la esencia es solamente el sentido y el valor de la cosa [...] En el fondo, siempre es la pregunta: ¿Qué es lo que es para mí?»?.

El fenomenal trabajo de Nietzsche en su Genealogía... muestra la condición cruel de todo pensamiento pero, sobre ello, muestra la crueldad calculadora con que la metafísica oculta la condición cruel de todo pensamiento. Para desandar este camino, hay que hacer de los métodos genealógico y filológico, instrumentos de ruptura hasta, finalmente y con el oído dolido de martillazos, dar con los fondos ásperos sobre los que se construye el fundamento del saber metafísico.

Sostendremos nuestro trabajo en estos dos lineamientos nietzscheanos mencionados anteriormente: el derecho de las obligaciones como procedencia de los conceptos metafísicos; la genealogía y la filología como instrumentos de des-cristalización conceptual. Sobre estas bases, intentaremos echar luz sobre la pregunta ¿en qué condiciones inventó la filosofía el concepto de nada?8; descubriremos en el andar que también la "nada» filosófica es, en sus inicios épicos, un juicio de valor medible bajo el criterio aristocrático del páthos de la distancia.

Presentaremos la problemática en tres movimientos sustentados en la épica homérica y apoyados por versos de la lírica y la tragedia griegas: «el nombre», donde situaremos los términos anónymos y oútis en un entramado de politización; "el nadie», donde haremos foco en el uso calificativo del término outidanós y esbozaremos la hipótesis de su inscripción en el vocabulario de las transacciones sociales; «la nada», donde abriremos la posibilidad de la asimilación del uso calificativo del outidanós épico en los términos medén/oudén.

7. Deleuze, G.: Nietzsche y la filosofía. Anagrama: Barcelona, 1986, p.110.

8. En este sentido, y siguiendo en la línea nietzscheana, reformulamos la pregunta que abre La Genealogía de la Moral: "Un poco de aleccionamiento histórico y filológico, y además una innata capacidad selectiva en lo que respecta a las cuestiones psicológicas en general, transformaron pronto mi problema en este otro: ¿en qué condiciones se inventó el hombre esos juicios de valor que son las palabras bueno y malvado?, ¿y qué valor tienen ellos mismos?" (Ibidem, p.24) 


\section{El nombre}

Los feacios están deseosos de un nombre. El rey increpa a Ulises ${ }^{9}$; te honramos, te dimos regalos y te ofrecimos hospedaje:

no me ocultés, huésped, lo que quiero saber de tu boca, y que a vos mismo te toca decir. Hablá, decí cómo te llamaban allí tu padre y tu madre, tus vecinos y los que habitaban los pueblos cercanos. Porque no hay mortal que carezca de nombre una vez que nació, no importa cuán miserable sea, pues a todos, después de engendrarlos, sus padres ponen un nombre. Decí cuál es tu país, tu ciudad y tu raza. ${ }^{10}$

"ou mèn gàr tis pámpan anónymós est' anthróponn" "1, no hay nadie que sea anónimo. Lo engendrado lleva nombre y el nombre lleva un padre, un pueblo, un país, una ciudad, un linaje. Ser nónymnos está ligado a la muerte literal por simbólica; no dejar nombre, no poder trascender por haber perdido la pertenencia: el peligro de «que los aqueos perezcamos aquí lejos de Argos sin dejar nombre (nónymnos)»12, lo terrible de que "Ítaca acabe sin gloria (nónymnos) $)^{13}$. Sucede como si el peligro de la guerra no fuese la muerte individual, sino el silenciamiento de las mallas relacionales que trama el nombre: del individuo a la familia, a la tribu, a las generaciones en línea descendente y ascendente, hasta alcanzar un héroe que alcanza un dios que asienta lazos con algún poder que brota de la phýsis. En una guerra donde se pelea a gloria u olvido, cada nuevo triunfo implica la mayor pervivencia de un nombre que lleva consigo todo un tejido de poder. En una guerra donde se pelea a recuerdo o infamia, cada derrota indica la caída hacia la insignificancia. Un pueblo anónimo es un pueblo infame ${ }^{14}$ y un nadie es un pronombre indefinido, un no hombre condenado a una errancia sin suelo. Tener nombre es pertenecer(se) en un elemento prestigioso capaz de correr los límites de la muerte, ascendiendo y descendiendo generacionalmente hasta congraciarse con las bondades divinas: «Entre quienes el morir es destino, ¿por qué uno debería consumir, en la oscuridad sentado en vano, una vejez sin nombre (anónymos),

9. Homero: Odisea, 8.536ss. Nos valemos de la traducción de M. Pabón; sin embargo, nos diferenciamos de esta traducción en preferir el voseo dialectal americano en la segunda persona del singular. Esta preferencia se reitera en la mayoría de las citas de los textos clásicos.

10. Ibídem, 8.547-555. Las cursivas son nuestras, resaltando el verso sobre el que focalizaremos en las líneas siguientes.

11. Ibídem, 8.552. Las negritas son nuestras, adelantando el núcleo de nuestra tematización: «nadie» en su identificación con «anónimo».

12. Homero: Ilíada, 12.70; 13.227; 14.70.

13. Homero: Od., 14.182 .

14. Ibídem, $1.222 ; 13.239$.

Thémata. Revista de Filosofía №54 (2016) pp.: 93-110. 
privado de toda cosa bella?» ${ }^{15}$; no habló en vano y el dios le dio un carro de oro y corceles de alas incansables. El nombre funciona como transmisión de «lo propio»: transmisión de un poder individual pero, además, de su carácter transitivo que va y viene, por la sangre de la pólis, hacia la raza; como una especie de «ley de los ancestros» que, en última instancia, señala la relación con un poder más allá de lo humano. La pérdida del nombre es proporcional en sentido inverso: signo de «impropiedad», pérdida de lazos $\mathrm{y}$, al final de la trama, desamparo (humano y divino) que se refleja en el castigo de un destierro que pervive en el destino trágico:

te juro por Zeus y por el suelo de esta tierra que nunca he tocado a tu esposa, ni podría haberlo deseado ni concebido. ¿Que perezca sin fama (akleés), sin nombre (anónymos), sin patria (ápolis), sin casa (áoikos) y vagando desterrado (phylás) por la tierra, que ni la tierra ni el mar acojan mi cadáver, si yo soy un hombre malvado!16

grita Hipólito señalando el cuerpo de Fedra. El contrapunto del anonimato es ser ápolis ${ }^{17}$; al margen de cualquier forma árquica (en el doble sentido del principio como comienzo y como comando), el sin nombre queda fuera del espacio político más allá de la vida y más acá de la muerte, desterritorializado en cuerpo y en cadáver. En el reverso de este mismo sentido, el nombre es marca de acción territorializadora: pertenencia vital a una pólis al tiempo que perpetuación en el modo de una inmortalidad de trascendencia política. El nombre, desde la universalidad de la filiación, es huella de politización. Lo que se revela en el deseo de nombre es la pervivencia de la pertenencia, recuerdo de genitivo; finalmente, Helena es "de» Troya. En el reverso de esta misma revelación, el terror al anonimato se nos aparece como temor a una muerte que es también, siempre y por definición, finitud política.

Es en las palabras de Ártemis a Hipólito donde puede comprenderse lo que se juega, épica o trágicamente, en el nombre: «el amor que Fedra sintió por ti no caerá anónymos»" ${ }^{18}$ que sólo puede traducirse por "en el silencio», «en el olvido» o "en el silencio del olvido» (o viceversa). Como si lo que se jugase en el crimen no fuera la vida aquí y ahora, sino el nombre en un allí y un entonces que abarca todos los tiempos y cualquiera de los espacios. Porque lo que efectivamente se juega no es la inmanencia del cuerpo o del cadáver, sino la posibilidad trascendente de un nombre en la memoria

15. Píndaro: Olímpicas, I.81-88.

16. Eurípides: Hipólito, 1025-1031.

17. Para la relación pólis-ápolis, cfr. Cuesta Abad, J.M.: Ápolis. Dos ensayos sobre la política del origen. Losada: Argentina, 2006.

18. Eurípides: Hip., 1429.

Thémata. Revista de Filosofía №54 (2016) pp.: 93-110. 
filial de un presente que permanece. La muerte y sus consecuencias retan a un duelo de recuerdo o de destierro.

«Dáme vino, no escatimes, y sepa yo al punto tu nombre; te voy a hacer un regalo de huésped que va a alegrarte..$^{19}$ Ulises sabe que en tierra ciclópeida en el nombre se va su carne. "Oûtis me llamaron mi padre, mi madre y mis amigos. $»^{20}$ Los versos del canto 9 reconfiguran el sentido de los términos "ou»-«tis»-«anónymós" adelantados en el canto $8^{21}$.

La métis de Ulises le permite el acto de resistencia heroica en las trampas del lenguaje. Porque el nadie de Ulises no es la clausura a una identidad, sino la estrategia de una inteligencia que le permite resistir en una cueva donde la antropofagia burla la ley hospitalaria que marca los límites de cualquier civilidad posible. En tierras donde "la abstracta desnudez de no ser nada más que humanos era su mayor peligro» ${ }^{22}$, Ulises sabe que ser Oûtis lo arrima a no estar y le permite, en el paréntesis del no estando, seguir el regreso a una identidad acabada. Esconder el nombre está directamente vinculado a la necesidad de ocultamiento, a la invisibilización del linaje, la ciudad y la raza; con ello, a la neutralización de la condición humana. Bajo la nomenclatura Síndrome de Ulises pasará a los anales de la psiquiatría este paréntesis del no estando:

«La confusión podría estar ligada con el tener que esconderse, hacerse invisible, para no ser retenidos, repatriados (en definitiva el famoso episodio de la Odisea en que Ulises le dice a Polifemo que su nombre es Nadie).» ${ }^{23}$ Vuelto un sin valor por la palabra, el héroe evita ser incorporado a un sistema que lo devora. Pero Ulises no soporta ser un nadie, no lo soporta ni siquiera ante la lejanía de un monstruo ciego por el engaño, ni siquiera hasta completar el engaño, ni siquiera sabiendo que su nadie no era de hecho ni de derecho, sino de juego de palabras, ni siquiera a riesgo de convulsionar las aguas en las que ya está navegando. Porque en el anonimato se va su supervivencia de héroe; como si tuviese que romper el con-

19. Homero: Od. 9.355-6.

20. Ibidem, 9.366-7.

21. Cfr. Senn, F.: The Odyssey through Joycean lenses, Hyperion, volume VIII, N², 2014, p.133 ss., en un formidable análisis de la Odisea desde la perspectiva de Joyce.

22. Arendt, H.: Los orígenes del totalitarismo, Madrid, Taurus, 1974, p.424. La cita se da en un contexto cronológico absolutamente alejado; sin embargo, la demarcación "política» del acontecimiento Ulises y los Cíclopes permite el análisis bajo la noción de nuda vida.

23. Achostegui, J.: Emigrar en situación extrema: el Síndrome del inmigrante con estrés crónico y múltiple (Síndrome de Ulises), Norte de Salud Mental, n²1, 2004, p.47. La cita sigue: "Así no es infrecuente encontrar casos de menores que han pasado por numerosos centros tutelados en los que dan un nombre diferente en cada lugar. ¿Cuál es el verdadero?». Para este tema, cfr. Cuestas: Mi nombre es nadie y nadie me llaman todos... Sobre la identidad del inmigrante, Rev. Inter. Mob. Hum., Brasilia, Año XXI, n 40,2013, pp.211-228.

Thémata. Revista de Filosofía N54 (2016) pp.: 93-110. 
juro de ser oútis ante lo terrible de volverse infame, ante lo terrible de que Ítaca acabe sin gloria y entonces Ulises acabe sin patria. « $i C h e$, Cíclope! Si alguna vez alguno de los mortales te pregunta quién fue el que te dejó ciego, le contestás que Ulises, el destructor de ciudades, nacido de Laertes y que tiene sus casas en Ítaca» ${ }^{24}$

Si y sólo si Ulises deja de ser nadie, se viene la ira de Poseidón. Y se viene. Porque Ulises es Ulises.

\section{El nadie}

Polifemo, ya ciego, acaricia a su carnero fiel: «si tuvieras palabra, me dirías en qué sitio se esconde, y haría estallar sus sesos en la cueva y se calmarían así los dolores que me causó en el pecho este outidanòs Ồ$t i s »^{25}$. Entre un héroe que porta la fonología como arma de supervivencia ${ }^{26}$ y la brutal inocencia de un caníbal gigante, Homero explota una notable distinción semántica: en el mismo verso 460 aparece, junto a Oûtis, outidanós. Calificando al nombre Oûtis está el adjetivo outidanós, derivado de la negación del pronombre indefinido tis. El diccionario define: que no cuenta, sin valor, en Homero referido siempre a personas; al tiempo que esboza una probable unión del sufijo -anós y la palabra oútid, de la que no hay mayor información que «una forma temprana de oúti (nada)» ${ }^{27}$.

Mourelatos ${ }^{28}$, retomando el trabajo de Moorhouse ${ }^{29}$ sobre los usos de oudeís y médeis, llama la atención sobre el uso calificativo ${ }^{30}$ del término outidanós, extendiéndolo a un uso calificativo de la nada en el desarrollo

24. Homero: Od. 9.502-505.

25. Ibídem, 9.456-460.

26. «El nombre Oûtis es perispómeno de acuerdo a la regla... de un sustantivo disilábico de este tipo, mientras el pronombre oútis es acentuado como un compuesto. La huida de Ulises del Cíclope se debió en no menor medida a su conocimiento de la fonología griega.» (Landsman, 1988-1989, p.17) Landsman: The History of some Greek Negatives: Phonology, Grammar and Meaning, Glossologia 7-8, 1988-1989 p.17.

27. Liddell, Scott, R. y Jones: Greek-English Lexicon. Oxford: Clarendon Press, 1940. Liddell y Scott: An Intermediate Greek-English Lexico. Oxford: Clarendon Press, 1889.

28. Mourelatos:"Nothing' as 'Not-Being': Some Literacy Contexts that Bear on Plato" en Anton, J.P. \& Preus, A. (editors), Essays in Ancient Greek Philosophy, vol. 2. New York: State University of New York, 1983, pp.59-69.

29. Moorhouse: A Use of oudeís and medeís. Class. Quart., N.S., 15, 1965, pp.31-40.

30. El characterizing use de la nada, que Mourelatos distingue del existencial use. Creemos que el uso que Mourelatos llama characterizing puede ser correctamente entendido no sólo como uso calificativo, sino como uso clasificativo; más aún, clasificativo en razón de su condición (des)calificante.

Thémata. Revista de Filosofía N54 (2016) pp.: 93-110. 
arcaico posterior. Este uso, señala Mourelatos, está dado por el adjetivo peyorativo outidanós, «un nadie», "una persona que no cuenta, un sin valor, un bueno para nada»; el "pronombre indefinido homérico oútis, del que deriva outidanós, sólo tiene el uso existencial de nadie, nunca el uso calificativo» ${ }^{31}$. En este esquema, oútis parece remitir al criterio de (in)existencia al tiempo que outidanós reconoce cierta existencia para, calificándola en su tipo, clasificarla no como clase nula, sino como una clase al margen del universo de los seres de valor, algo así como la clase complemento del conjunto los valiosos. De este modo, en el verso 460, Ulises negaría su propia existencia con el Oûtis al tiempo que Polifemo negaría el valor de Oûtis con el atributo outidanós, debiendo necesariamente reconocer el valor existencial de Oûtis para poder devaluarlo a través del mecanismo de la (des)calificación.

Resultaría interesante hipotetizar la posibilidad de un adjetivo vinculado a la familia semántica de dános (habitualmente traducido por regalo). «La palabra dános, 'préstamo', puede originalmente haber significado la parte del sacrificio dada al sacerdote. El significado de éranos pasa de la comida común al préstamo de dinero.» ${ }^{32}$

Benveniste ${ }^{33}$ explica que dános es un término técnico para el préstamo a interés, vinculado con daneízo (prestar a interés), daneizomai (pedir prestado), daneistés (deudor); cercano etimológicamente a daí $\underline{0}$, datéomai (repartir), glosando el término méros (la parte). Con esto, dános se vincula a un "préstamo a interés» vinculado a "la parte» en una "repartición»; dános se inscribe, así, dentro "del vocabulario de las transacciones sociales» ${ }^{34}$ refiriendo a la parte que toca en la distribución, en este caso, del botín de guerra: "lo que hemos saqueado de las ciudades está repartido (dédastai)" 35 . En una lógica donde «negarse a dar [...] equivale a declarar la guerra, pues es negar la alianza y la comunión. Se dá porque se está forzado a dar, ya que el donatario goza de una especie de derecho de propiedad sobre todo lo que pertenece al donante» ${ }^{36}$, el don no tiene que ver con una gratuidad común sino con el peso grave de una autoridad que mide unilateralmente su valor en la relación del dar y el recibir, en una relación de distancia entre animales tasadores. En el poema de una fuerza

31. Mourelatos, op. cit., p.60.

32. Seaford, R.: Money and the early Greek Mind. Homer, Philosophy, Tragedy. United Kingdom: Cambridge University Press, 2004, p.79.

33. Benveniste, E.: Vocabulario de las instituciones indoeuropeas. Madrid: Taurus, 1983, pp.126 ss.

34. Ibidem, p.127.

35. Homero: Il., 1.125.

36. Mauss, M.: Sociología y Antropología. Madrid: Editorial Tecnos, 1979, pp.168 s. Para el caso de Agamenón y Aquiles, $c f r$. Finley, M.: El mundo de Odiseo. México: Fondo de Cultura Económica, 1977, pp.115 ss.

Thémata. Revista de Filosofía $\mathrm{N}^{\circ} 54$ (2016) pp.: 93-110. 
donde el dar no tiene que ver con la equilibrada reciprocidad del don sino con el incremento del poder del quién da más y el quién más tiene, el valor es marcado por la parte en el reparto. Cuenta el que recibe y mantiene lo recibido; Briseida por Criseida para que quien manda siga ejerciendo su valer. «Es mucho más cómodo en el vasto campamento de los aqueos quitar los regalos (dwron) al que hable en contra tuyo. ¡Rey devorador del pueblo (démobóros), porque reinas entre nadies (outidanô̂sin)! $!{ }^{37}$, le grita Aquiles a Agamenón mientras se resiste a ser un outidanós devorado por un rey que sólo entregará su parte cuando reciba la parte del que vale casi lo mismo que él. El tema de la «medición» del valor entre Aquiles y Agamenón constituye el nudo gordiano de la cólera de Aquiles, quien hace explícita la «medida» de la amenaza: botín por botín. Cada vez que los aqueos saquean una ciudad, "nunca tengo un botín igual al tuyo» ${ }^{38}$, dice Aquiles, sin importar que sean sus manos las que soportan el fragor de la batalla. Porque cuando llega el reparto, «tu botín es mucho mayor, y yo, con un lote menudo, aunque grato, me voy a las naves, después de haberme agotado de combatir» ${ }^{39}$. Por eso, a causa de este desequilibrio entre la «fuerza» de la lucha y el «poder» de la recompensa, Aquiles decide la retirada: «ahora me marcho a Ftía, porque realmente es mucho mejor ir a casa con las corvas naves, y no tengo intención de procurarte riquezas y ganancia estando aquí deshonrado.» ${ }^{40}$ Agamenón duplica la apuesta, reforzando la explicitación de la amenaza y elaborando la medida del valor por "comparación": «[...] puede que me lleve a Briseida [...], para que sepas bien cuánto más poderoso soy que tú, y aborrezca también otro pretender ser igual a mí y compararse conmigo. ${ }^{41}$

La ira de Aquiles es efecto del entramado de una lógica del valor traicionado, donde cada parte vale un pedazo de gloria. Aún habiendo entregado a la muchacha, Aquiles deja claro que ninguna otra pertenencia le será quitada ${ }^{42}$ : «outidanós se me podría llamar si es que voy a ceder ante

37. Homero: Il. 1.229-231.

38. Ibidem, 1.163 .

39. Ibidem, 1.167-168.

40. Ibidem, 1.169-171.

41. Ibidem, 1.184-187.

42. «Le interrumpió y respondió Aquiles, de la casta de Zeus: 'De verdad que cobarde y outidanós se me podría llamar si es que voy a ceder ante ti en todo lo que digas. A otros manda eso, pero no me lo ordenes a mí, que yo ya no pienso obedecerte. Otra cosa te voy a decir, y tú métetela en tus mientes: con las manos yo no pienso luchar por la muchacha ni contigo ni con otro, pues me quitáis lo que me disteis. Pero de todo lo demás que tengo junto a la veloz nave negra, no podrías quitarme nada ni llevártelo contra mi voluntad. Y si no, ea, inténtalo, y se enterarán también éstos: al punto tu oscura sangre manará alrededor de mi lanza.» (Il. 1. 292-303)

Thémata. Revista de Filosofía N54 (2016) pp.: 93-110. 
ti en todo lo que digas» ${ }^{43}$ No será llamado un nadie (outidanós) porque no dará más de lo que le fue repartido y guarda en su nave; Aquiles no dejará de valer porque no cederá ya ninguna otra parte de las que le hacen ser aquello que vale.

La parte del botín de guerra, así como de los premios de juego, está inscripta en una implícita noción de cuantificación que hace a una génesis del valor que terminará estructurando los orígenes de la lógica monetaria. En este contexto, las cosas dadas como premio (copas, fuentes, trípodes, armas, etc) son entendidas como signos de valor que, leídos desde los principios monetarios, serán convertidos en signos premonetarios. "Estos objetos aparecen generalmente con un número: los rescates y los regalos de hospitalidad llevan una cifra que deja constancia de tradiciones, de normas [...] existe toda una jerarquía de valores entre los premios. Por eso varios objetos de este tipo están en relación directa con los inicios de la moneda.» ${ }^{44}$ Lo que los premios valen por sí mismos, hace valer a su poseedor, quedando también él inscripto en esta misma secuencia cuantificadora.

Los nadies son, en la política épica, los que no cuentan en el número del reparto, apartados del ser valioso por su insignificancia de no tener; luego, en una torsión anímica que puede revisarse en la Poética de Aristóteles ${ }^{45}$, los cobardes, buenos para nada, cercanos en la debilidad a una mujer o a un niño ${ }^{46}$. Es de estos nadies, que no califican en la cuenta de la gloria, de quienes sólo parece quedarnos el término outidanós, el atributo de una clase para los sin nombre; ni siquiera gracias a su enfrentamiento con los valiosos, sino a razón de la colisión interna de un poder que se destina a devorarlos.

43. Homero: $I l$. 1.293-4

44. Gernet: Antropología de la Grecia Antigua. Madrir, Taurus, 1980, p.87.

45. Aristóteles: Poética. Madrid: Gredos, 1999, 1458b. En una contribución a la claridad de la elocución y la necesidad de evitar su vulgaridad, Aristóteles recomienda el uso de vocablos «usuales»: «la mesura es necesaria en todas las partes de la elocución; en efecto, quien use metáforas, palabras extrañas y demás figuras sin venir a cuento, conseguirá lo mismo que si buscase adrede un efecto ridículo [...] Lo ventajoso que es, en cambio, su uso conveniente, puede verse en los poemas épicos introduciendo en el verso los vocablos corrientes. Quien sustituya la palabra extraña, las metáforas y demás figuras por los vocablos usuales verá que es verdad lo que decimos» -las cursivas son nuestras-. En este contexto, Aristóteles cita el verso 515 del canto 9 de la Odisea, y reemplaza «outidanòs kaì aeikés" por "asthenikòs kaì aeidés"s.

46. Crf. Homero: Il. 11.390.

Thémata. Revista de Filosofía N54 (2016) pp.: 93-110. 


\section{La nada}

Barbara Cassin se vale de Homero para mostrar la «herencia ontológicamente cargada ${ }^{47}$ de la negación, usando de testigo varias lenguas que muestran la doble faz positiva/negativa y su facilidad de inversión; entre ellas, el español, donde la palabra nada ofrece una síntesis de la evolución del sentido etimológico de "cosa» invertida en "nada»: el español nada está construido sobre el latín [res] nata, participio pasado de nasci (nacer), con lo cual la nada es, en su génesis etimológica, una nacida. Es decir, la carga de la negación muestra la torsión de sentido de una identidad positiva. "Y cuando no es la entidad positiva la que directamente vira de sentido, la diferencia y la inventiva de las lenguas se leen en la elección de lo que se niega $\|^{48}$. El griego niega con ou y con $m \underline{e}^{\underline{4}}$; ; oú/tis y mée/tis (ninguno, todo salvo alguno, nadie) niegan el pronombre indefinido tis; ou/deís y $\mathbf{m e}$ / deís (ni siquiera uno, ninguno) niegan el adjetivo numeral masculino hềs (uno) ${ }^{50}$; ou/dén y mêldén niegan el mismo adjetivo hén (uno) en neutro. Debajo de la entidad positiva girando de sentido, debemos preguntarnos qué niegan los griegos cuando afirman la nada.

Mourelatos ${ }^{51}$, que discute el hábito de la metafísica oficial de asimilar lo que no es (tò mẹ ón) a nada (mêdén/oudén $)^{52}$ bajo el criterio del bi-

47. Cassin, B.: «El au-sentido, o Lacan de la A a la D» en Badiou, A. \& Cassin, B. No hay relación sexual. Madrid: Amorrortu, 2010, pp.74ss.

48. Ídem. Las cursivas son nuestras.

49. La distinción clásica entre ou y mè determina que ou niega hechos, siendo del orden de lo objetivo al tiempo que mè es una negación del orden de lo modal, constituyéndose en subjetiva.

50. «La expresión usual en Homero para «ninguno es oútis/métis. Las formas oudamòs/ médamós, compuestos por oudélmédè y hamós, una forma antigua de «uno» son mencionados como formas tempranas por los gramáticos Apolonio Discolo y Herodio, y encontramos las formas plurales de éstos en Heródoto (ej. Hist. 1.18, 24, 143, 144, etc.) y los adverbios oudamàl

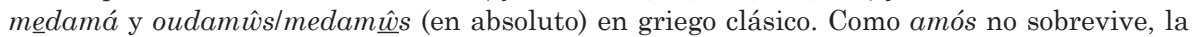
conexión entre estos negativos y «uno» se vuelve muy poco obvia. Mientras oudamós/médamós no se encuentran en el griego clásico en su forma singular, un número considerable de compuestos adverbiales son creados, especialmente en el siglo IV» (Landsman: The History of some Greek Negatives: Phonology, Grammar and Meaning, Glossologia 7-8, 1988-1989, p.19). En griego clásico, explica Landsman, los términos oudeis / medeís cubren el vacío dejado por oudamòs/medamós. Cfr. Malcom: Plato's Analysis of tò ón and tò mè ón in the Sophist". Phron. XIII, 1967, p.135 n.13 y pp.135 ss, donde desarrolla una diferencia semántica entre tò mè ón y tò médamôs ón, objetando la identidad entre ser y existencia en el Sofista de Platón.

51. Mourelatos, A.P.D.: Op. cit.

52. Para esta asimilación, Mourelatos remite a Parménides B6.2, B7.1, B8.7-13, B9.4 (Kirk, G.S, Raven, J.E. \& Schofield, M: «Parménides de Elea» en Los filósofos presocráticos, Gredos: Madrid, 1987, pp.346-376); Platón, Rep. 478B12-C1, Teet. 189A10, Sof. 237C7-E2. Asimismo, sostiene sus argumentaciones en Owen, G.E.L: Plato, I, Metaphysics and Epistemology. New York: Garden City, 1971.

Thémata. Revista de Filosofía №54 (2016) pp.: 93-110. 
nomio existencia/inexistencia, propone una lectura en la que los términos oudeís/médeís y oudén/médén en el período arcaico, expanden su uso asimilando el uso calificativo del outidanós homérico. En este sentido, hablar de un sujeto que es nada implica no su inexistencia sino el reconocimiento de que un sujeto tal no cabe dentro de la clasificación de quien predica su nada; es decir, el ser nada se acerca al sentido jurídico de nuestro no ha lugar: una existencia de la que se predica la nada simplemente no reúne las condiciones deseables que legitiman el acceso al universo clasificado positivamente.

De este modo, se abre la inmensa posibilidad hermenéutica de leer los orígenes arcaicos de la nada: por un lado, desde la distinción entre un/ una nadie/nada existencial y un/una nadie/nada atributivo/a; y adherido, por un otro lado yuxtapuesto, a la procedencia político/social de tal distinción. Para comprender esta inmensa posibilidad, resulta sugestivo traer a la mente la concepción de nada esbozada en los «Escritos de Juventud de Marx», que se alinea en una aguda crítica a la ontología que subyace a la economía capitalista. En un sistema que identifica al hombre con la clase «trabajador», aquél que no está incluido en un contrato de salario, resulta nada para el sistema; es decir, el sistema lo (des)califica como nada (sin valor) desde la clase valiosa de trabajador/asalariado:

«La economía política ignora al trabajador desocupado, al hombre de trabajo situado fuera de la relación de trabajo. El pícaro, el bribón, el mendigo, el trabajador desocupado, hambriento, miserable y criminal son figuras que no existen (nicht existeren) para ella, sino solamente para otros ojos, los del médico, los del juez, los del enterrador, el fiscal de pobres, etc., fantasmas que vagan fuera del reino de la economía política». ${ }^{53}$

La cita de Marx grafica acabadamente esta lógica selectiva que subyace subrepticiamente en la categoría de nada de una ontología política y que, en términos del propio Marx, se resume en la caída de una nada incumplida a una nada absoluta (das absolute Nichts) en la forma de la inexistencia social (gesellschaftliches Nichtdasei) y, por lo tanto, real ${ }^{54}$.

En los fondos de esta argumentación, se vuelve necesario reconocer que la nada es funcional a un sistema de selecciones que no se sostiene sobre un pulcro binomio lógico sino sobre la fuerza de un páthos de la distancia en el sentido más nietzscheanamente político. En la Sexta Oda Nemeica, Píndaro ${ }^{55}$ compara el genós de los hombres y el genós de los dioses; ambos nacidos de la misma madre pero separados por un poder (dýnamis)

53. Marx, C.: Obras Fundamentales, tomo I. México: Fondo de Cultura Económica, 1982, p.606.

54. Ibidem, p.607.

55. Píndaro: «Nemeas» en Odas y fragmentos. Madrid: Gredos, 1984, pp.242-3.

Thémata. Revista de Filosofía $\mathrm{N}^{\circ} 54$ (2016) pp.: 93-110. 
del todo diverso, de modo que el genós de los hombres es nada (oudén). Es nada (oudén), se entiende, comparado con el genós de los dioses; en el mismo sentido en que Agamenón incorporaba la medida del valor por comparación ${ }^{56}$. El uso clasificador que parece poner en movimiento la nada es la marca de la distancia entre niveles de poder (dýnamis). La raza de los mortales es nada frente a los inmortales; los infames son nada frente a los héroes; los muertos son nada frente a los vivos ${ }^{57}$. Toda elevación del tipo «hombre» ha sido hasta ahora, dice Nietzsche ${ }^{58}$,

«obra de una sociedad aristocrática...: una sociedad que cree en una larga escala de jerarquía y de diferencia de valor entre un hombre y otro hombre... el páthos de la distancia... surge de la inveterada diferencia entre los estamentos, de la permanente mirada a lo lejos y hacia abajo dirigida por la clase dominante sobre los súbditos e instrumentos, y de su ejercitación, asimismo permanente, en el obedecer y el mandar.»

El páthos de la distancia constituye el entre de la brutal separación en un arriba clasificador y un abajo clasificado, el entre la fuerza infinitamente superior de quien tasa el reparto y la permanente supeditación atributiva de quien se queda sin parte.

En este contexto de un Nadie (Oûtis) que remite a un nadie (outidanós) que, bajo la lógica de la «repartición» remite a nadies (outidanói) que se categorizan en nada (oudén/medén), el páthos de la distancia muestra el poder selectivo de esa "vieja hembra engañadora»" ${ }^{59}$, en un proceso en que el atributo lógico se hace libra de carne. Este páthos de la distancia que Nietzsche realza como condición de una clase superior creadora de valores, es también la marca de las «pasiones instituyentes» de la pólis: «en la raíz de la institución primordial hay una «voluntad» y una intención prelógicas, y las instituciones no pueden mantenerse sin pasión» ${ }^{60}$; las astunómous orgás que Sófocles vincula a las palabras y el pensamiento que el hombre se enseña a sí mismo ${ }^{61}$ y que Heidegger decide traducir por «la pasión de dominación sobre las ciudades» (der Mut der Herrschaft über die Städte $)^{62}$. Disposiciones, pulsiones, instintos «instituyentes» que señalan

56. Cfr. aquí mismo, nota 34 .

57. «Acoge a la que nada (tền médèn) es en la nada (tò mêdén)» (Sófocles, Electra, 1166)

58. Nietzsche, F.: Más allá del bien y del mal. Madrid: Alianza, 1986, p.219.

59. Así refiere Nietzsche a la "gramática». Nietzsche, F: Crepúsculo de los ídolos. Madrid: Alianza, p.55.

60. Castoriadis, C.: "Antropogonía en Esquilo y autocreación del hombre en Sófocles» en Figuras de lo pensable. Fondo de Cultura Económíca de Argentina: Buenos Aires, 2006, p.31.

61. Sófocles, Antígona 355-356.

62. Heidegger, M.: Introducción a la metafísica. Gedisa: Barcelona, 1999, p.136. Contra esta traducción carga todas sus armas Castoriadis, considerando la traducción como «claramente nazi» y literalmente «aberrante» (op.cit., p.31).

Thémata. Revista de Filosofía $\mathrm{N}^{\circ} 54$ (2016) pp.: 93-110. 
la profunda raíz «pasional» del ordenamiento de las instituciones pero que, también y más profundamente, develan la terribilidad (deinós) ${ }^{63}$ del hombre: un animal que no cesa de agotar [la tierra para su beneficio] (apotruétai $)^{64}$, de encarcelar [los pájaros] (ágei ${ }^{65}$, de hacerse dueño [de las bestias salvajes] (krateî) $)^{66}$ y de enseñarse a sí mismo (didásketai) ${ }^{67}$; es decir, las pasiones instituyentes que, en términos de Nietzsche, «justifican a $e l$ hombre» ${ }^{68}$ en el sentido de reconocer, fluyendo por debajo de toda abstracción conceptual, la prepotencia de una fortaleza que es «un querer-dominar, un querer-sojuzgar, un querer-enseñorearse, una sed de enemigos y de resistencias y de triunfos» ${ }^{69}$.

Dentro del "poema de la fuerza», la Ilíada canta el encauzamiento de la fuerza en los límites del derecho ${ }^{70}$; ciudad en paz dentro del escudo bestial de una ciudad en guerra; disposiciones, pulsiones, pasiones encauzadas dentro del desborde arrogante de fuerzas dispositivas, pulsionales y pasionales que hacen al relato principal. Los hombres están reunidos en el mercado, dirimiendo la pena por un asesinato; uno insiste en que pagó lo que correspondía mientras el otro niega haber recibido nada (mêdén). Sólo una vez aparece medén en Homero, en medio de un pasaje que ha dado qué hablar a la posteridad. Los ancianos darán su dictamen; en medio del círculo está la recompensa para la sentencia más recta: dos talentos de oro. La primera aparición de la nada está vinculada con el valor, en lo que podría entenderse como una de las más antiguas composiciones de los mecanismos de administración de una justicia que nace como juicio de valor.

Por debajo del acostumbrado papel de la nada como fiel acompañante metafísica de un ser que es, puede provocarse al pensamiento para buscar las raíces políticas de lo que no hay en una ideología épica donde cada quien es por lo que vale y vale por lo que tiene, insinuando sujetos de derecho aún antes de la categorización del derecho y sus sujeciones, y reconvirtiendo los bienes comunes en propios aún antes de la categorización

63. Sófocles, Antígona, 334 .

64. Ibidem, 338.

65. Ibidem, 344.

66. Ibidem, 349.

67. Ibidem, 352 .

68. Nietzsche, F.: La genealogía de la moral. Alianza: Madrid, 2001, p.58.

69. Ibidem, p.59.

70. Homero: $I l$. 18.497-508.

Thémata. Revista de Filosofía №54 (2016) pp.: 93-110. 
de la propiedad. Debajo de la entidad positiva girando de sentido, debemos preguntarnos a quiénes niegan los griegos cuando afirman su(s) nada(s).

\section{Conclusión}

¿En qué condiciones inventó la filosofía el concepto de nada? es el interrogante que nos conduce. Podríamos reformularlo preguntando cuáles son las procedencias materiales de una conceptualización que identifica la nada con el no ser. Para abrirnos a la pregunta, debemos suponer que el pensamiento filosófico inicia mucho antes que la filosofía. Amparados en tal supuesto, y bajo la convicción de que el afán tendencioso de la filosofía es «sustituir las relaciones reales de fuerza por una relación abstracta, supuesta capaz de expresarlas todas» ${ }^{71}$, trabajamos la posibilidad de retrotraer la nada filosófica de carácter existencial a una nada épica de carácter atributivo.

Leer el recorrido trabajado en sentido inverso al expuesto, puede ayudarnos a concluir un resumen de nuestra argumentación: la nada (medén/oudén) en su carácter de no ser puede remitirse a una inexistencia que califica a los nadies (outidanói) en una lógica de la parte en el reparto propia de las transacciones distributivas de un pensamiento épico cuyo dispositivo de poder es la gloria. Para ello, el nudo de la argumentación se aglutina en una hipótesis que, en sus tecnicismos, deberá discutirse en el campo de la filología: la remisión del término outidanós al término dános.

En nuestra introducción, señalábamos un camino nietzscheano que marca a los conceptos morales como la procedencia de la ascesis metafísica, y a los derechos de las obligaciones, como el campo de procedencia de la conceptualización moral, formando la siguiente línea de abstracción: derechos de las obligaciones - conceptos morales - ascesis metafísica. Nuestro discurrir recorre el punto de partida y el punto de llegada de esta misma senda: la abstracción de la nada como no ser (no haber) tiene su hogar nativo en la más antigua y originaria relación en que los hombres se miden entre sí por aquello que hay: Agamenón y Aquiles, quien se queda con más y quien se queda con menos, quien vuelve a repartir cuando le quitan su parte, tasador y tasado; pero, en esta relación en la que el ser se mide por el poder que se mide por el valer que se mide por el tener, surge la mención de un término que se corresponde con nada: outidanós. Es outidanós aquel que no tiene y por ello no vale y por ello no puede y por ello no es. La causa

71. Deleuze, G.: op. cit., p.106.

Thémata. Revista de Filosofía №54 (2016) pp.: 93-110. 
de la cólera de Aquiles es su temor de ser nadie, valiendo nada. El ardid de Odiseo es volverse nadie para, valiendo nada, dejar de ser.

Solo un término nos llega de los nadie, un término y nada más; «lo que les arrancó de la noche en la que habrían podido, y quizá debido, permanecer, fue su encuentro con el poder. Sin este choque ninguna palabra sin duda habría permanecido» ${ }^{72}$. La cólera de Aquiles y la astucia de Odiseo nos arrojan una palabra que Occidente entierra en el olvido; una palabra que tiñe de infamia y anonimato los fundamentos metafísicos de la nada.

Tal vez debamos exigirnos una genealogía de la nada, como «la historia de lo denegado que sin embargo relampaguea aquí y allá prepotentemente, aunque de manera episódica" 73 , como el llamado de una potencia inquietante que representa una posibilidad justa ante la opresión infame de un ser clasificador que no cesa de anonadar(nos).

\section{Referencias bibliográficas}

Achostegui, J.: Emigrar en situación extrema: el Síndrome del inmigrante con estrés crónico y múltiple (Síndrome de Ulises), Norte de Salud Mental, n 21, 2004, pp.39-52.

Arendt, H.: Los orígenes del totalitarismo. Madrid: Taurus, 1974.

Aristóteles: Poética. Traducción de V. García Yebra, Madrid: Gredos, 1999.

Benveniste, E.: Vocabulario de las instituciones indoeuropeas. Madrid: Taurus, 1983.

Cassin, B.: «El au-sentido, o Lacan de la A a la D» en Badiou, A. \& Cassin, B. No hay relación sexual. Madrid: Amorrortu, 2010, pp.13-86.

Castoriadis, C.: "Antropogonía en Esquilo y autocreación del hombre en Sófocles» en Figuras de pensable. Fondo de Cultura Económica de Argentina: Buenos Aires, 2006, pp.13-34.

Cuesta Abad, J.M.: Ápolis. Dos ensayos sobre la política del origen. Losada: Argentina, 2006.

Cuestas, F.: Mi nombre es nadie y nadie me llaman todos... Sobre la identidad del inmigrante, Rev. Inter. Mob. Hum., Brasilia, Año XXI, n 40, 2013, pp.211-228.

Deleuze, G.: Nietzsche y la filosofía. Anagrama: Barcelona, 1986.

Eurípides: «Hipólito» en Tragedias I. Madrid: Gredos, 2000,

72. Foucault, M.: La vida de los hombres infames. Argentina: Editorial Altamira, 1996, p.124.

73. Givone, S.: Historia de la nada. Buenos Aires: Adriana Hidalgo, 2011, p.11.

Thémata. Revista de Filosofía $\mathrm{N}^{\circ} 54$ (2016) pp.: 93-110. 
pp.171-236.

Finley, M.I.: El mundo de Odiseo. México: Fondo de Cultura Económica, 1977.

Foucault, M.: La vida de los hombres infames. Argentina: Editorial Altamira, 1996.

Galeano, E.: «Los nadies» en El libro de los abrazos. Ediciones Siglo XXI, 1989, p.52.

Gernet, L.: Antropología de la Grecia Antigua. Madrid: Taurus, 1980.

Givone, S.: Historia de la nada. Buenos Aires: Adriana Hidalgo, 2011.

Heidegger, M.: Introducción a la metafísica. Gedisa: Barcelona, 1999.

Homero: Mliada. Traducción de E. Crespo Güemes, Madrid: Gredos, 2000.

Homero: Odisea. Traducción de J. M. Pabón, Madrid: Gredos, 1993.

Kirk, G.S, Raven, J.E. \& Schofield, M: «Parménides de Elea» en Los filósofos presocráticos, Gredos: Madrid, 1987, pp.346-376.

Landsman, D.M.: The History of some Greek Negatives: Phonology, Grammar and Meaning, Glossologia 7-8, 1988-1989, pp.13-31.

Liddell, H.G, Scott, R. \& Jones, H.S.: A Greek-English Lexicon. Oxford: Clarendon Press, 1940.

Liddell, H.G. \& Scott, R.: An Intermediate Greek-English Lexicon. Oxford: Clarendon Press, 1889.

Malcolm, J.: «Plato's Analysis of tò ón and tò mè ón in the Sophist». Phron. XIII, 1967, p.130-146.

Marx, C.: Obras Fundamentales, tomo I. México: Fondo de Cultura Económica, 1982.

Mauss, M.: Sociología y Antropología. Madrid: Editorial Tecnos, 1979.

Moorhouse, A.C.: A Use of oudeís and medeís. Class. Quart., N.S., 15, 1965, pp.31-40.

Mourelatos, A.P.D.: «Nothing' as 'Not-Being': Some Literacy Contexts that Bear on Plato» en Anton, J.P. \& Preus, A. (editors), Essays in Ancient Greek Philosophy, vol. 2. New York: State University of New York, 1983, pp.59-69.

Nietzsche, F: Crepúsculo de los ídolos. Madrid: Alianza, 2010.

Nietzsche, F.: La genealogía de la moral. Alianza: Madrid, 2001.

Nietzsche, F.: Más allá del bien y del mal. Madrid: Alianza, 1986.

Owen, G.E.L: Plato, I, Metaphysics and Epistemology. New York: Garden City, 1971.

Píndaro: «Nemeas» en Odas y fragmentos. Traducción de A. Ortega, Madrid: Gredos, 1984, pp.217-274.

Píndaro: «Olímpicas» en Odas y fragmentos. Traducción de A. Ortega, Madrid: Gredos, 1984, pp.73-140.

Platón: República. Traducción de C. Eggers Lan, Madrid: Gredos, 1998.

Platón: Sofista. Traducción de N.L. Cordero, Madrid: Gredos, tomo 
V, 2000, pp.313-472.

Platón: Teeteto. Traducción de A. Vallejo Campos, Madrid: Gredos, tomo V, 2000, pp.133-312.

Seaford, R.: Money and the early Greek Mind. Homer, Philosophy, Tragedy. United Kingdom: Cambridge University Press, 2004.

Senn, F.: The Odyssey through Joycean lenses, Hyperion, volume VIII, N²2, 2014, pp.111-137.

Sófocles: "Electra» en Tragedias. Traducción de A. Alamillo, Madrid: Gredos, 2000, pp.197-258.

Sófocles: "Antígona» en Tragedias. Traducción de A. Alamillo, Madrid, pp.69-128. 